\title{
Factors Affecting Propensity to Export: The Case of Indonesian SMEs
}

\author{
Mohamad Dian Revindo, ${ }^{* 1}$ Christopher Gan, ${ }^{1}$ Natanael Waraney Gerald Massie ${ }^{1}$ \\ ${ }^{1}$ Universitas Indonesia, Indonesia \\ ${ }^{2}$ Lincoln University, New Zealand
}

\begin{abstract}
The benefits of trade liberalization are not shared equally among countries and enterprises across the globe. Small and Medium-sized Enterprises (SMEs) in developing countries are less able to participate in export markets than their larger counterparts, despite various export assistance provisions by their governments. This study aims to investigate the factors influencing Indonesian SMEs' decisions and ability to engage in direct export activities. The evidence was collected from 271 exporting SMEs and 226 non-exporting SMEs in seven provinces in Java, Madura, and Bali. Logistic regressions were used to identify the distinct characteristics of the exporting SMEs. The findings show that the exporters differ from non-exporters in terms of their firms' and owners' characteristics, their perceptions toward export barriers, their participation in their national government's export assistance program and network relationships. The academic, policy and managerial implications of the findings are discussed.
\end{abstract}

Keywords: SMEs, firm internationalization, export engagement, export propensity, export barriers, Indonesia

JEL Classification: F23, L25, M16 


\section{Introduction}

Trade liberalization brings about challenges as well as opportunities for firms across the globe. It forces local firms to compete with cheaper imported products and multinational enterprises, while providing them with opportunities to export, adopt foreign technologies and operate in foreign markets (Awuah and Amal, 2011; Knight, 2000; Shu and Steinwender, 2019). However, the benefits of trade openness are not spread equally among countries and enterprises. Despite the growing importance of developing countries in world trade, 34 OECD member states still accounted for $56-62 \%$ of the world's merchandise export value during 2010-2018 (ITC, 2019).

At the business level, large enterprises are more prepared to capitalize on trade opportunities compared to Small and Medium-sized Enterprises (SMEs). For example, SMEs in the US, Switzerland, the Netherlands, the United Kingdom, China, and Japan only contribute $30-38 \%$ to their respective total national exports (Hammer and Stamps, 2010). The SMEs' meager export contributions are even more prevalent in developing countries. For example, SMEs in the ASEAN member states only accounted for $23 \%$ of the total exports, on average (Wignaraja, 2012; Yoshino and Wignaraja, 2015).

Likewise, in Indonesia, the SMEs' share (including that of the micro enterprises') of total export was minuscule despite being a major source of business establishments, employment opportunities, and value-added creation ${ }^{1}$. SMEs make up approximately $99.99 \%$ of the total business entities, provide

\footnotetext{
${ }^{1}$ Prior to the implementation of the Law No. 20 (Republic of Indonesia, 2008), the "Small-sized Enterprise" term generally included small and microenterprises.
}

more than $97 \%$ of job opportunities and contribute around $60 \%$ of the Indonesian GDP (Indrawan, 2019). By contrast, despite the steady rise in Indonesia's total annual exports' value, the SMEs' share in non-oil and gas exports continually shrank from around $18.5 \%$ in $2005-2007$ to $16.9 \%$ in $2008-2010$, and further down to $15.4 \%$ between 2011 and 2013 (Ministry of Cooperatives and SMEs, Republic of Indonesia, 2015) 2 .

Thus, Indonesian SMEs are less able to take advantage of export opportunities from trade liberalization compared to their larger counterparts; they fare less well in export performance compared to SMEs in other ASEAN countries and perform far below the SMEs in developed countries. The SMEs' poor export performance persists despite various policy measures launched by the Government of Indonesia, including general assistance (such as access to credit, technical and managerial training), as well as specific export-related assistance (including trade promotions, business matching, and training in export procedures).

Our study aims to investigate the factors influencing the Indonesian SMEs' engagement in the export market. Specifically, the paper aims to answer the following questions: i) What are the main factors stimulating SMEs to export? ii) What are the main barriers hampering the SMEs' exports? iii) What are the main characteristics distinguishing exporting and non-exporting SMEs? In order to answers these questions, we adopted a framework proposed by Shih and Wickramasekera (2011), in which the SMEs' involvement in exporting is determined by three

\footnotetext{
${ }^{2}$ If oil and gas exports are included, SMEs' and micro-enterprises' contribution might be even lower since oil and gas exports are performed by large stateowned enterprises. Wignaraja (2012) estimated SMEs' contribution to Indonesia's total exports was at $9.3 \%$.
} 
forces: export enhancing factors, export inhibiting factors and the SMEs' characteristics.

The significance of the study is threefold. For academics, the study enriches the general framework of the SMEs' export market involvement, developed by Shih and Wickramasekera (2011), with a comprehensive set of explanatory variables, including nine export-enhancing factors, 50 types of export barriers and five SMEs' characteristics. Further, the study adds to the limited evidence from Indonesia, to discover which SMEs are increasingly exposed to challenges and opportunities from trade liberalization. ${ }^{3}$ For the SMEs' owners and managers, the study shows how they can speed up their internationalization process through the development of network relationships with formal and informal institutions.

The remainder of the paper is organized as follows. Section 2 reviews the theoretical and empirical literature on the SMEs' propensity for export market engagement. Section 3 presents the method, including the data source and the data analysis method. Section 4 discusses the empirical results. Finally, Section 5 concludes with a summary of the main research findings and the implications of the research.

\footnotetext{
${ }^{3}$ By September 2019, Indonesia had 11 FTAs in effect, including ASEAN (1993), ASEAN-China (2010), ASEAN-Australia and New Zealand (2010), ASEANIndia (2010), ASEAN-Japan (2008), ASEAN-Korea (2007), Indonesia-Japan (2008), Indonesia-Pakistan (2013), Indonesia-Chile (2017), Indonesia-EFTA CEPA (2018) and Indonesia-Australia (2019). Indonesia also has ongoing negotiations with several other regional and bilateral FTAs.
}

\section{Literature Review}

\section{Conceptual Framework of SMEs' Export Engagement}

SME internationalization has been studied separately from general firm internationalization due to the SMEs' particular characteristics, such as their size and limited resources, which may constrict their international business activities (Dabić et al., 2019; Laghzaoui, 2007; Ribau et al., 2018; Ruzzier et al., 2006). Owing to their lack of resources, SMEs are averse to the risk of failure in international market operations. Hence, SMEs cautiously evaluate the expected benefits and costs of exporting before deciding to venture abroad. Following Bernard and Jensen (2004) and Ottaviano and Martincus (2011), in the case that export engagement is a one-period decision, a firm formally maximizes its profits from exporting as follows:

$\pi_{i t}\left(q_{i t}^{*}, Z_{i t}, Y_{i t}\right)=p_{i t} q_{i t}^{*}-c_{i t}\left(q_{i t}^{*}, Z_{i t}, Y_{i t}\right)$

Where $\pi_{i t}$ is the export profit of firm $i$ in period t. The firm's export revenue is the price of the exported products $\left(p_{i t}\right)$ times the profit-maximizing level of the exports $\left(q_{i t}^{*}\right)$. The variable cost of producing the exported goods $\left(c_{i t}\right)$ is the function of $q_{i t}^{*}$ a vector of firm-specific features $\left(Z_{i t}\right)$ and a vector of the environmental factors that are exogenous to the firm, but affect its probability of exporting $\left(Y_{i t}\right)$.

Therefore, the firm exports if the expected revenue exceeds the expected costs: $X_{i t}= \begin{cases}1 & \text { if } \pi_{i t}\left(q_{i t}^{*}, Z_{i t}, Y_{i t}\right)=p_{i t} q_{i t}^{*}-c_{i t}\left(q_{i t}^{*}, Z_{i t}, Y_{i t}\right)>0 \\ 0 & \text { if } \pi_{i t}\left(q_{i t}^{*}, Z_{i t}, Y_{i t}\right)=p_{i t} q_{i t}^{*}-c_{i t}\left(q_{i t}^{*}, Z_{i t}, Y_{i t}\right) \leq 0\end{cases}$ 
Where $X_{i t}$ is a binary variable representing firm is export status at period $\mathrm{t}$ (one $=$ exporting, zero $=$ otherwise).

However, the firm may face export decisions in multiple periods (i.e. a sporadic exporter or a previous exporter). In this case, in addition to the variable costs, the firm also faces a sunk cost of foreign market entry (Bernard and Jensen, 2004; Ottaviano and Martincus, 2011; Roberts and Tybout, 1997). The costs of gathering information and establishing distribution systems in target markets, respectively, are a few examples of the costs of entering a foreign market. The entry cost is sunk in nature and thereby the firm that has already exported in the previous period does not have to pay during the current or future period. Hence, the firm's profit maximization from export activities is given as follows:

$\pi_{i t}\left(q_{i t}^{*}, Z_{i t}, Y_{i t}\right)=p_{i t} q_{i t}^{*}-c_{i t}\left(q_{i t}^{*}, Z_{i t}, Y_{i t}\right)-N\left(1-X_{i t-1}\right)$
Where $\mathrm{N}$ is the sunk entry cost and $X_{i t-1}$ is the firm's export status in the previous period (one $=$ exported in the past, zero $=$ otherwise). Hence, the firm's export decision in period $t$ is as follows: $X_{i t}=\left\{\begin{array}{l}1 \text { if } p_{i t} q_{i t}^{*}>c_{i t}\left(q_{i t}^{*}, Z_{i t}, Y_{i t}\right)+N\left(1-X_{i t-1}\right) \\ 0 \text { if } p_{i t} q_{i t}^{*} \leq c_{i t}\left(q_{i t}^{*}, Z_{i t}, Y_{i t}\right)+N\left(1-X_{i t-1}\right)\end{array}\right.$

Despite their strong and clear insights, those revenue-cost models are difficult to estimate in the absence of precise measures and data, in terms of the product's price in foreign markets and the variable costs of production. Alternatively, the export decision model can also be treated as the result of the factors that enhance exporting, the factors that inhibit exporting and firm characteristics (Shih and Wickramasekera, 2011) (see Figure 1). In this model, the enhancing factors may include the perceived benefits of exporting or the factors that stimulate exporting, such as government export assistance and network relationships. The inhibiting factors may include the cost of exporting and the perceived export bar-

\section{Enhancing Factors \\ - Government's export assistances \\ -Network relationships}

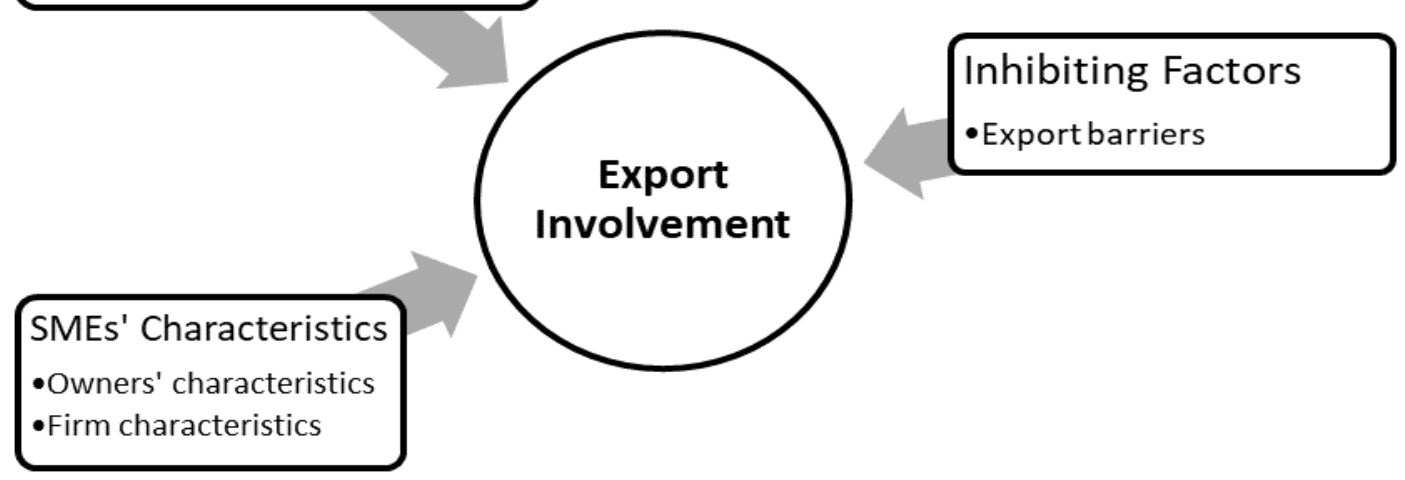

Source: Adopted from Shih and Wickramasekera (2011)

Figure 1: Conceptual Framework of Export Engagement Decision 
riers. Participation in the export market can be estimated with a probabilistic model with maximum likelihood estimation techniques (i.e. probit or logistic regression analysis).

\section{Empirical Studies}

The extant literature shows the growing research interest into the determinants of SMEs' engagement in export markets. Evidence has been provided from various countries, for example, Haddoud, Beynon, Jones, and Newbery (2018) looked at SMEs in North Africa, García-Cabrera, García-Soto, and Suárez-Ortega (2017) in Spain, Fakih and L. Ghazalian (2014) in the Middle East and the North African region, Shih and Wickramasekera (2011) in Taiwan, Yang, Leone, and Alden (1992) in the USA, Ottaviano and Martincus (2011) in Argentina, and Roberts and Tybout (1997) in Colombia.

However, in the case of Indonesia, there are few comprehensive empirical works that shed light on its SMEs' propensity to export, as the extant studies mostly looked at a particular aspect or determinant of export engagement. For example, some studies examined various export enhancing factors including entrepreneurship, human capital and social capital (Sari, 2011; Sari, Alam, and Beaumont, 2008), networking and information dispersion (Revindo and Gan, 2016; Senik and Sham, 2011), the government's industry and trade facilitation (Tambunan, 2009a, 2009b), product competitiveness (Firmanzah, 2008) and the adoption of information and communication technology (Putra and Hasibuan, 2015). Some other studies rather focused on the export barriers hampering SMEs exports, including Revindo (2018) and Tambunan (2012). Summing up, the extant literature on the internationalization of In- donesian SMEs still falls short of explaining the SMEs' propensity to engage in exporting activities and lacks generalizability of the results, due their partial approach to the topic.

\section{Methods}

\section{Estimation Method}

We depart from the theoretical framework that explains SMEs' export decisions as a function of the expected monetary revenue and expected costs of exporting activities (i.e. if the expected export revenue exceeds the expected cost of exporting, as shown in equations 1-4) (Ottaviano and Martincus, 2011; Roida and Sunarjanto, 2012; Yi and Wang, 2012). We instead follow Shih and Wickramasekera (2011) who proposed a more general model of export engagement in which the export decision is determined by enhancing factors, inhibiting factors, and firm characteristics (illustrated in Figure 1). The main reason is that in the pilot survey we found that accurate financial information about the SMEs was difficult to obtain. Many SMEs did not have good bookkeeping systems and many others were reluctant to reveal their financial information.

Since we aim to predict SMEs' export engagement with a set of explanatory variables, and the target variable is a binary choice of SMEs' export engagement (to export or not to export), an Ordinary Least Square (OLS) regression is not statistically appropriate (Hill, Griffiths, and Lim, 2011; Maddala, 2001). Instead, we employ a binary logistic regression model to predict the probability of firm i engaging in export activities, given a set of enhancing factors, inhibiting factors, and firm characteris- 
tics. Formally, the binary logit model procedure can be briefly explained as follows.

$$
P_{i}=E\left(E X P O R T_{i}=1\right)=\frac{1}{1+e^{-z_{i}}}
$$

Where EXPORT is firm is export engagement status, which is equal to one if the firm is an exporter and equal to zero if the firm is a non-exporter; $P_{i}$ is firm is estimated probability of export engagement (high value of $P_{i}$ implies a high probability to become an exporter); and

$z_{i}=\alpha+\sum_{j=1}^{n} \beta_{j} \operatorname{STIMULI}_{i j}+\sum_{k=1}^{p} \gamma_{k}$ BARRIERS $_{i k}+\sum_{l=1}^{q} \delta_{l}$ FIRM $_{i l}+\epsilon_{i}$

Where $S T I M U L I_{i j}$ is a vector of export stimuli; BARRIERS $_{i k}$ is a vector of export barriers; FIRM $_{i l}$ is a vector of firm characteristics; and $\epsilon_{i}$ is the error term. The notations $n, p$ and $q$ represent the total number of variables representing export stimuli, export barriers, and firm characteristics, respectively. The symbols $\alpha, \beta, \gamma$ and $\delta$ represent the constant and the vector of coefficients for the export stimuli, export barriers, and firm characteristics, respectively.

As Equation(5) represents the cumulative logistic distribution function, the probability of not engaging in export activities is given by:

$$
\left(1-P_{i}\right)=\frac{1}{1+e^{z_{i}}}
$$

Thus, the odds of observing an exporting SME $\left(E X P O R T_{i}=1\right)$ over non-exporting SMEs $\left(E X P O R T_{i}=0\right)$ is:

$$
\frac{P_{i}}{1+P_{i}}=\frac{1+e^{z_{i}}}{1+e^{-z_{i}}}=e^{z_{i}}
$$

Taking the natural logarithm of Equation (8), we obtain:

$$
\ln \left(\frac{P_{i}}{1-P_{i}}\right)=Z_{i}
$$

Hence, $Z_{i}$ (in Equation 9) is the natural logarithm of the odds ratio in favor of observing exporting SMEs.

To obtain efficient parameter estimates, the logistic model uses maximum likelihood estimation techniques. The observed EXPORT $_{i}$ is the realization of a binomial process with probabilities given by Equation 5 that vary by individual firm (depending on $Z_{i}$ ). Hence, the likelihood function (L) can be written as follows (Maddala, 2001):

$$
L=\prod_{E X P O R T_{i=1}} P_{i} \prod_{E X P O R T_{i}=0}\left(1-P_{i}\right)
$$

We carry out two binary logistic estimations with two different sample subsets. In the first estimation, we investigate the factors that distinguish exporting and non-exporting SMEs. Thus, the dichotomous dependent variables take the values of one for exporters and zero for non-exporters. In the second estimation, we focus on investigating the factors that distinguish exporting SMEs and non-exporting SMEs with intention/plan to export (aspiring-exporters). Hence, the dichotomous dependent variable takes the value of one for exporters and zero for aspiring-exporters.

Table 1 provides the description and the expected signs of the independent variables (the hypothesized relationship between the independent variables and the probability of SMEs' export engagement). The SMEs' characteristics are represented by firm age, total number of employees and the owners' gender, age and educational attainment. Export enhancing factors are represented by the 
owners' overseas study, training or work experience, international company experience, assistance received from the central govern- ment, local government and non-government actors, the product and the location. The export inhibiting factors are repre-

Table 1: Independent Variables for the Export Engagement Model

\begin{tabular}{|c|c|c|}
\hline Variables & Description & Priori Sign \\
\hline \multicolumn{3}{|c|}{ Export Stimuli/Enhancing Factors } \\
\hline OwnerStudy Abroad & $\begin{array}{l}\text { SME owner's overseas study experience, where } 1 \text { if SME } \\
\text { owner ever studied overseas, } 0 \text { otherwise. }\end{array}$ & + \\
\hline OwnerTrainAbroad & $\begin{array}{l}\text { SME owner's training/short courses experience, where } 1 \\
\text { if SME owner ever had training/short courses overseas, } \\
0 \text { otherwise. }\end{array}$ & + \\
\hline OwnerWork Abroad & $\begin{array}{l}\text { SME owner's overseas work experience, where } 1 \text { if SME } \\
\text { owner previously worked overseas, } 0 \text { otherwise. }\end{array}$ & + \\
\hline OwnerWorkMNC & $\begin{array}{l}\text { SME owner's MNC/export firm work experience, where } \\
1 \text { if SME owner previously worked with MNC or export } \\
\text { firms, } 0 \text { otherwise. }\end{array}$ & + \\
\hline GovCentral_Assist & $\begin{array}{l}1 \text { if SME received promotional, business management, } \\
\text { finance, or production assistance from any central gov- } \\
\text { ernment agencies. }\end{array}$ & + \\
\hline GovtLocal_Assist & $\begin{array}{l}1 \text { if SME received technical or managerial training, grants } \\
\text { or promotional assistance from any local (provincial, re- } \\
\text { gency, or municipal) government agencies. }\end{array}$ & + \\
\hline NonGovt_Assist & $\begin{array}{l}1 \text { if SME received any type of assistance from business } \\
\text { associations/chambers, universities/research institutes, } \\
\text { private companies/SOEs, business partners/associates, } \\
\text { family/relatives, or Indonesian emigrant communities. }\end{array}$ & + \\
\hline ProductXNational & $\begin{array}{l}\text { SME's type(s) of product's share in Indonesia's total na- } \\
\text { tional non-oil and gas export. }\end{array}$ & + \\
\hline ProvinceXNational & $\begin{array}{l}\text { Province's share in Indonesia's total national non-oil and } \\
\text { gas exports. }\end{array}$ & + \\
\hline \multicolumn{3}{|l|}{ Inhibiting Factors } \\
\hline Export Barriers & $\begin{array}{l}\text { Factor scores/summated scale of export barrier compo- } \\
\text { nents/ dimensions resulting from the principal compo- } \\
\text { nent's analysis. }\end{array}$ & - \\
\hline \multicolumn{3}{|c|}{ SMEs Characteristics } \\
\hline FirmAge & $\begin{array}{l}\text { Number of years the firm has been operating since firm's } \\
\text { establishment at the time of the survey. }\end{array}$ & + \\
\hline TotalEmployee & Total number of employees. & + \\
\hline OwnerGender & Owner's gender, where $1=$ male, $0=$ female. & $+/-$ \\
\hline OwnerAge & Owner's age at the time of the survey. & + \\
\hline OwnerEducation & $\begin{array}{l}\text { Owner's educational attainment, where } 1=\text { primary } \\
\text { school or no } \\
\text { formal education, } 2=\text { junior or senior high school, } 3= \\
\text { college, } \\
\text { diploma or vocational school, } 4=\text { bachelor's degree, } 5= \\
\text { postgraduate degree. }\end{array}$ & + \\
\hline
\end{tabular}


sented by the perception of the difficulties of various export barriers. We identified 50 specific export barrier types/items, previously developed by Leonidou (2004), OECDAPEC (2006), and OECD (2012). We expect each type of export barrier to have negative correlations with the SMEs' export engagement. The more difficult the SMEs perceive a type of export barrier to be; the less likely they are to become exporters. However, we first reduce the 50 export barrier items into a smaller number of variables underlying the broader dimensions of export barriers using the PCA. The summated scales/ factor scores for each extracted and retained factor/component are calculated and used as input data in the regression model.

\section{Data}

This study focuses on small-sized and medium-sized enterprises and excludes micro-sized and large-sized enterprises ${ }^{4}$. Among the various definitions of SMEs, two definitions are widely used in Indonesia:

1. The Ministry of Cooperatives and SMEs defines SMEs as enterprises with assets valued at Rp 50 million-Rp 10 billion (equivalent to approximately USD 3,571-714,286) or with an annual turnover of Rp 300 million-Rp 50 billion (equivalent to USD 21,429-3,571,429) (Republic of Indonesia, 2008). ${ }^{5}$

2. BPS-Statistics Indonesia defines SMEs as enterprises with 5-99 employees (BPS-Statistics Indonesia, 2014b).

\footnotetext{
${ }^{4}$ Micro enterprises are excluded for two reasons. First, the micro enterprises database is unavailable in Indonesia as they are mostly in the form of individual businesses or home industries. Second, micro enterprises are less likely to engage in international business (Pendergast et al., 2008).

${ }^{5}$ The exchange rate is assumed at Rp14,000/USD
}

During the pilot survey, we found that at the practical level, the identification of SMEs' assets and turnover value is difficult, laborious, and potentially inaccurate. The SMEs' asset valuation requires a complex appraisal method and their turnover estimations are not always available due to their poor bookkeeping. Hence, this study refers to the definition of SMEs by the number of employees (5 to 99) used by BPS-Statistics Indonesia. Despite its applicability, it is worth noting that this definition also has shortcomings. Most notably, defining SMEs by the number of employees has a potential bias towards that of capital-intensive industries. For example, this definition potentially includes some large-scale enterprises in capital-intensive industries that employ a small number of employees but excludes medium-scale enterprises in labour-intensive industries that employ large numbers of workers.

The total number of SMEs in Indonesia was estimated at around 700,000 units in 2014, (Ministry of Cooperatives and SMEs, Republic of Indonesia, 2015), approximately $70 \%$ of which were concentrated in only three islands: Java, Madura, and Bali (Sabila, 2014). This imbalanced distribution largely reflects the economic agglomeration pattern in Indonesia that causes economic activities to be mainly concentrated in those three closely-related islands. The three islands consist of only seven provinces and constitute only $7.07 \%$ of the country's total land area but are inhabited by $57.5 \%$ of the country's total population and generate over $58 \%$ of the country's total GDP/value added (BPS-Statistics Indonesia, 2014a). Hence, the target population of this study is the SMEs that are operating in seven provinces in Java, Madura, and Bali. The three islands also have better transportation and communication infrastructure than the rest of the country, allowing better access to survey 
the many SMEs that are spread throughout the islands within our time and budget constraints.

In order to construct the sample frame, we merged four different databases into one list of SMEs from which the samples were picked. The first three databases were published by the Ministry of Cooperatives and SMEs including (1) the Ministry of Cooperatives and SMEs' online trading board ${ }^{6}$; (2) SME and Cooperative Indonesia Catalogue (Ministry
To capture the SMEs' internationalization processes and determinants, it is important that our study sample consists of SMEs at different export stages, including exporting SMEs and non-exporting SMEs. The survey targeted at least 192 samples (half of the total calculated sample size of 384) for each exporting and non-exporting SME category (see Figure 2$)^{10}$. In addition, the total sample size was expanded by approximately $25 \%$ to

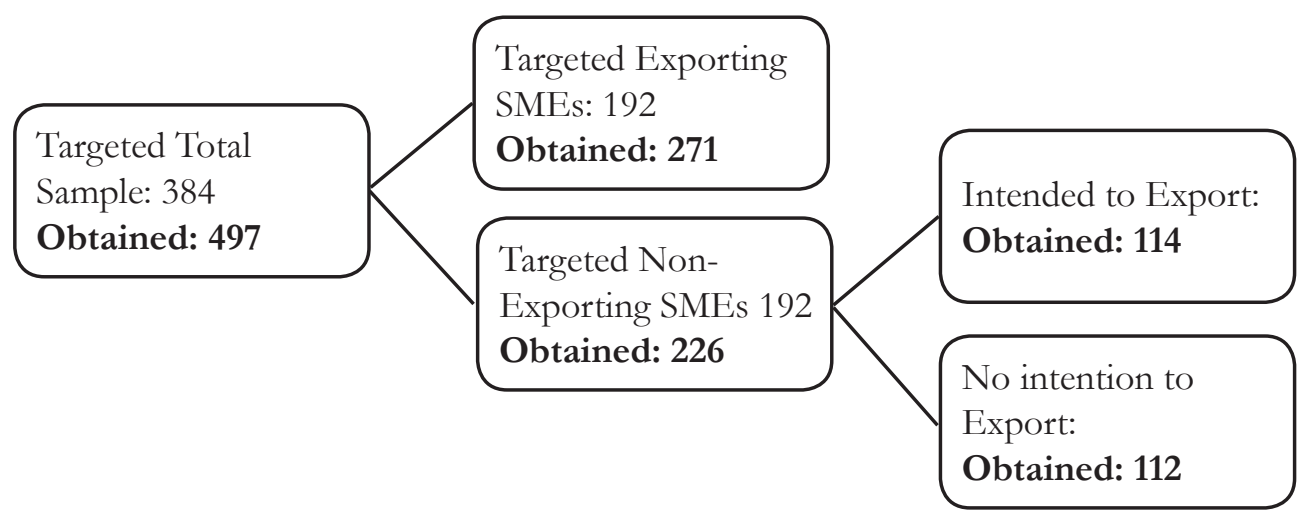

Figure 2: Sample Quota and Realization

of Cooperatives and SMEs Republic of Indonesia, 2011, 2012)7 ; and (3) Exporting SMEs Directory Book (Ministry of Cooperatives and SMEs Republic of Indonesia, 2009) $)^{8}$. The fourth database is the Indonesian Economic Census provided by BPS-Statistics Indonesia ${ }^{9}$.

\footnotetext{
${ }^{6}$ Online promotion at the website of the Ministry of Cooperatives and SMEs, http://www.indonesianproducts.biz.

The catalogue provides SMEs' contacts and products' description in four languages (English, Arabic, Japanese, and Indonesian). The catalogue is published annually as part of the ministry's promotion program.

${ }^{8}$ The directory books list all SMEs that participated in international trade shows organized by the Ministry of Cooperatives and SMEs' during 2005-2009.

9 The BPS-Statistics Indonesia (National Agency for Statistics) performs economic censuses every ten years. When the survey for this study was conducted in 2014, the most recent census was the 2006 national census while the next census would be conducted in 2016 and published in 2018.
}

increase the sample's sufficiency. However, stratified sampling was not applicable because the export status of most SMEs in the sample frame was unknown prior to the survey. Therefore, a quota random sampling method

\footnotetext{
${ }^{10}$ The population of SMEs in the study area $(\mathrm{N})$ is approximated to be around 490,000 (approximately $70 \%$ of the total Indonesian SME population of $700,000)$. Owing to this large size of the target population, the sample size (n) is not expected to exceed $5 \%$ of the population (less than 24,500 SMEs) due to time and budget constraints. Hence, the following sample size formula for an infinite population is appropriate (Anderson et al., 2010; Crossley, 2008; Lee et al., 1999): $n=\left(\frac{\left(z_{\alpha / 2}\right) \sigma}{M O E}\right)^{2}$, where $\mathrm{n}$ is the sample size; $\boldsymbol{Z}_{\propto / \mathbf{2}}$ is the value of the two-sided confidence interval in normal distribution, $\delta$ represents the variation of the variable of interest and MOE is the desired margin of error. Assuming that $\boldsymbol{Z}_{\propto / 2}=1.96$ (corresponds to a $95 \%$ confidence interval), response distribution $\sigma=0.5, \mathrm{MOE}=0.05$ and $\mathrm{N}=490,000$, the calculated sample size is 384 .
} 
was used, in which the sampled SMEs were drawn randomly from the sample frame and their export status was established after the survey. The procedure was repeated until each SME's export status category was filled.

The survey was administered in 2014. During the survey period, we contacted and approached 971 SMEs, 522 of which were willing to participate in the survey (a response rate of $53.76 \%$ ). 449 SMEs refused to participate in the survey, had shut down the business, or changed the number of employees beyond the 5-99 range. large number of responses were collected from the provinces of East Java (185 SMEs, including from Madura Island) and DKI Jakarta (100 SMEs). Both provinces are highly populated and industrialized. The remaining 212 respondents were distributed between the remaining five provinces (Banten, West Java, Central Java, DI Yogyakarta, and Bali).

Table 3 shows the distribution of surveyed SMEs by their products and export status. Seventy-four SMEs produce more than one type of product (multi products) while the remaining 423 SMEs spe-

Table 2: Sample Distribution by Province and Export Status

\begin{tabular}{lrrrrrr}
\hline \multirow{2}{*}{ Province } & \multicolumn{1}{c}{ Exporter } & \multicolumn{3}{c}{ Non-Exporter } & \multicolumn{3}{c}{ Total by Province } \\
\cline { 2 - 8 } & Count & $\%$ & Count & $\%$ & Count & $\%$ \\
\hline Banten & 11 & 4.1 & 4 & 1.8 & 15 & 3.0 \\
\hline DKI Jakarta & 56 & 20.7 & 44 & 19.5 & 100 & 20.1 \\
\hline West Java & 19 & 7.0 & 20 & 8.8 & 39 & 7.8 \\
\hline Central Java & 13 & 4.8 & 28 & 12.4 & 41 & 8.2 \\
\hline DI Yogyakarta & 53 & 19.6 & 6 & 2.7 & 59 & 11.9 \\
\hline East Java & 76 & 28.0 & 109 & 48.2 & 185 & 37.2 \\
\hline Bali & 43 & 15.9 & 15 & 6.6 & 58 & 11.7 \\
\hline $\begin{array}{l}\text { Total by Export } \\
\text { Status }\end{array}$ & 271 & 100.0 & 226 & 100.0 & 497 & 100.0 \\
\hline
\end{tabular}

Source: Author's calculation based on survey data.

Of the 522 returned questionnaires, 497 were usable while 25 were unusable due to incomplete responses. The usable responses consisted of 271 exporting SMEs and 226 non-exporting SMEs and therefore the targeted total sample size and the specified quota were fulfilled. Further, within the 226 non-exporting SMEs category, there were 114 SMEs with the intention and plans to export (aspiring-exporters) and the other 112 had no intention of exporting in the future, which added more variation to the sample.

Table 2 shows the distribution of the sample by province and export status. A cialise in a specific type of product, with the largest number producing handicrafts (91 SMEs) and the lowest number making machinery components (18 SMEs).

A structured questionnaire with close-ended questions was developed and translated into Indonesian. Before the SME survey was administered, the questionnaire was piloted randomly to 25 SMEs in the Greater Jakarta region. The pre-test was carried out to obtain feedback to improve the content of the questions and the instructions, and the clarity and layout of the questionnaire. The pre-test also gave important feedback 
Table 3: Sample Distribution by Product and Export Status

\begin{tabular}{lrrrrrr}
\hline Products & Exporter & \multicolumn{3}{c}{ Non-Exporter } & \multicolumn{2}{r}{ Total by Products } \\
\cline { 2 - 8 } & Count & $\%$ & Count & $\%$ & Count & $\%$ \\
\hline Agricultural Products & 23 & 8.5 & 8 & 3.5 & 31 & 6.2 \\
\hline Food \& Beverages & 17 & 6.3 & 39 & 17.3 & 56 & 11.3 \\
\hline Furniture & 43 & 15.9 & 37 & 16.4 & 80 & 16.1 \\
\hline Handicrafts & 59 & 21.8 & 32 & 14.2 & 91 & 18.3 \\
\hline Garments & 33 & 12.2 & 36 & 15.9 & 69 & 13.9 \\
\hline $\begin{array}{l}\text { Leather Products \& Fashion } \\
\text { Accessories }\end{array}$ & 15 & 5.5 & 17 & 7.5 & 32 & 6.4 \\
\hline Household Utensils & 15 & 5.5 & 12 & 5.3 & 27 & 5.4 \\
\hline Machinery Components & 7 & 2.6 & 11 & 4.9 & 18 & 3.6 \\
\hline Other Products & 9 & 3.3 & 10 & 4.4 & 19 & 3.8 \\
\hline Multi Products & 50 & 18.5 & 24 & 10.6 & 74 & 14.9 \\
\hline Total by Export Status & 271 & 100.0 & 226 & 100.0 & 497 & 100.0 \\
\hline
\end{tabular}

on the questionnaire's translation from English to Indonesian. Responding to the SME survey questions required a good knowledge of the enterprises' operational activities and therefore the questionnaires were administered to the SMEs' owners or managers.

\section{Result and Discussion}

\section{Export-Inbibiting Factors}

In the survey, all the respondents were asked to indicate how serious/difficult each export barrier item encountered by SMEs was on a three-point Likert-type scale. The Likert-type scale ranges from "not difficult" (response one), "difficult" (response two) to "very difficult" (response three) ${ }^{11}$.

Principal Component Analysis (PCA) was performed on the survey responses for the 50 export barrier items' Likert-type scale questions to reduce the dimensions of the

\footnotetext{
${ }^{11}$ For the use of a three point scale without a neutral scale in the survey for export barrier survey questions, see OECD (2012).
}

items into a smaller number of variables (principal components) that may represent a broader dimension of the export barriers. The correlation matrix indicates that 981 of 990 correlation values $(99.1 \%)$ are significant at the $5 \%$ level and Bartlett's test of sphericity is significant at the 1\% level, both of which indicate the appropriateness of PCA for the export barrier survey data. The KMO test value of 0.906 and the MSA value for each export stimuli item (all above 0.60 ) indicate the adequacy of the overall and individual items' sample size.

The PCA factor extraction was estimated five times which resulted in 45 retained export barrier items. Five export barrier items were eliminated from the analysis because the initial PCA factor extraction results showed that they either had a low level of communalities (below 0.40), showed cross-loadings problems, or had insignificant factor loadings (below 0.40). The PCA extracted all the factors with latent root criteria (eigenvalues) that exceeded one (i.e. no certain number of factors was specified to be ex- 
tracted). The PCA gave an 11 factor solution that explains $59.703 \%$ of the total variance.

Table 4 shows the rotated component matrix and the 11 extracted factors. Based on the export barrier items that have high loadings on each factor, the 11 factors that represent the 11 dimensions of export barriers are named as follows: tariff and non-tariff barriers in host countries; informational and human resources barriers, distribution, logistic, and promotional barriers; business environment barriers in host countries; product and transaction barriers; financial barriers; foreign government barriers; procedural barriers; price barriers; home government barriers; and foreign customer and competitor barriers respectively. Hence, we have 11 variables to represent the export barriers/ export inhibiting factors, named as follows: Barrier_Tariff, Barrier_Human, Barrier_Distribution, Barrier_ForeignEnviro, Barrier_Product, Barrier_Financial, Barrier_ForeignGovt, Barrier_Procedure, Barrier_Price, Barrier_Hom Govt, and Barrier_Customer. The data series for each export barrier variable was obtained from the PCA's factor scores and calculated using the regression score method $^{12}$.

\section{Binary Logit Estimation for Export- ers-Non-Exporters Model}

The specification tests of the exporter-non-exporters binary logit regressions are as follows. The Omnibus Tests of Model

\footnotetext{
${ }^{12}$ Factor scores can be calculated with non-refined methods (Sum Scores or Summated Scales) and refined methods (e.g. Regression Scores, Bartlett Scores, Anderson-Rubin Scores) (DiStefano et al., 2009). We used the Regression Score method to calculate the factor scores for the eleven variables that represent export barriers. However, we also simulated the factor score calculation with two other refined methods (Bartlett Scores and Anderson-Rubin Scores) and obtained very similar results.
}

Coefficients yield a Chi-square statistic of 311.130 with 25 degrees of freedom and is significantly different from zero at the $1 \%$ level. Moreover, the model's -2 Log likelihood value of 372.200 suggests that the model including the explanatory variables is a significantly better fit than the null model. These indicate that the explanatory variables employed in the models significantly improve the baseline model that only includes the constant. In other words, the 25 explanatory variables used in the model can significantly improve the model's ability to explain the variation of the outcome (i.e. SMEs' exporting or non-exporting status). In particular, the Cox and Snell Pseudo R-square of 0.466 and the Nagelkerke Pseudo R-square of 0.623 indicate that the model can explain a considerable share of the variations in the SMEs' export status (McFadden, 1977) ${ }^{13}$. The Hosmer and Lemeshow test yields a Chi-square value of 5.305 and $\mathrm{p}$ $=0.725(>0.05)$, which suggests the model is a good fit to the data. More precisely, the model (with 25 explanatory variables) has an $82.3 \%$ success in classifying/predicting the SMEs' engagement in exporting activities.

Table 5 exhibits the direction and the magnitude of the effect of each explanatory variable on the dependent variable. Fourteen explanatory variables have statistically significant estimated coefficients with expected signs except for ProvinceXNational. However, the value of the estimated coefficients from the logistic regression have no direct economic interpretation because they are obtained using maximum likelihood estimation tech-

\footnotetext{
${ }^{13}$ McFadden (1977) argued that for the estimation using the maximum likelihood estimation, the value of $\rho^{2}$ (Pseudo R-square) between 0.2 and 0.4 represents an excellent fit of the model. In this case, the full model (with all the explanatory variables) significantly improves the initial model with only the intercept as predictor.
} 
Revindo et al.

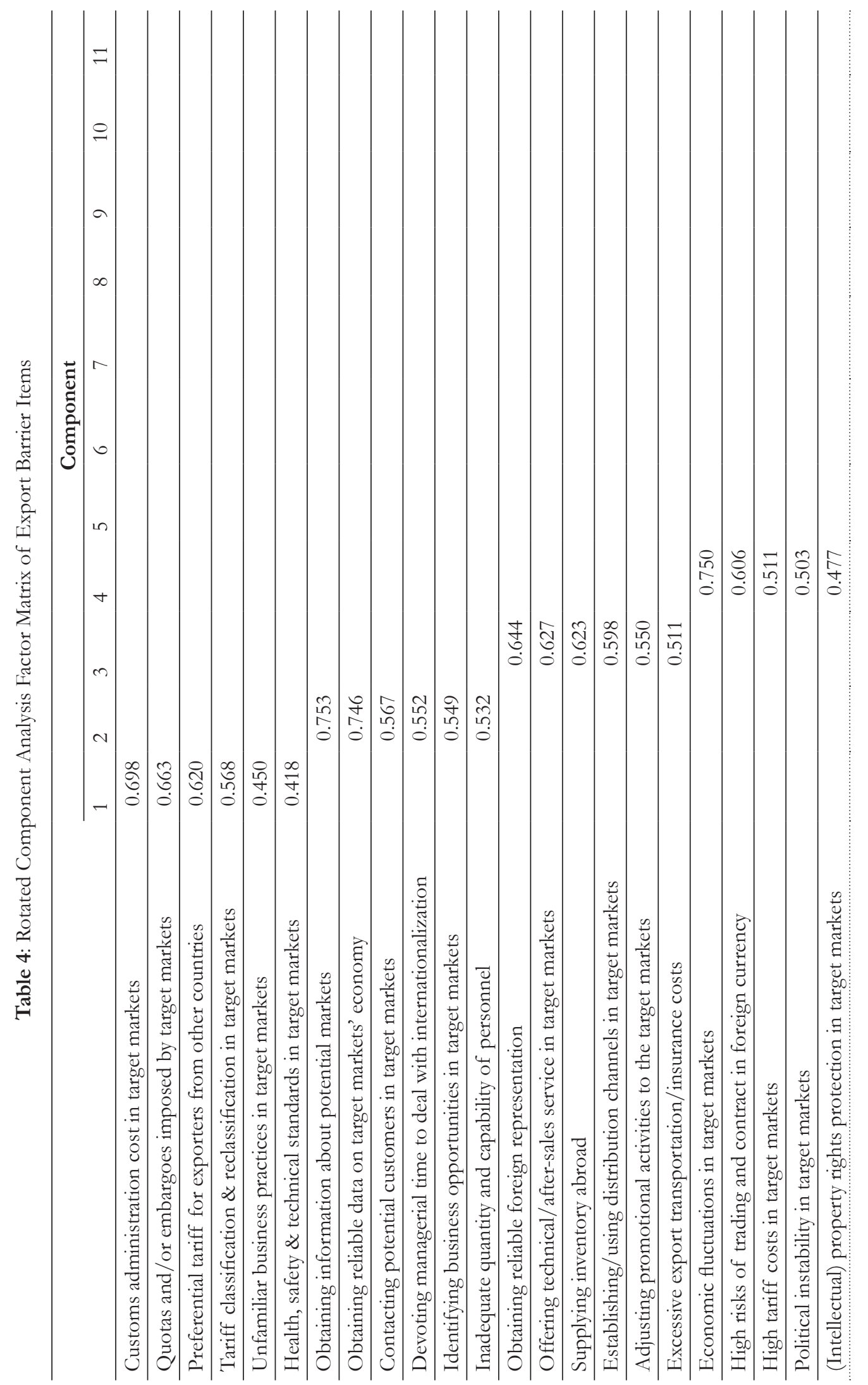


Gadjah Mada International Journal of Business - Sept.-Dec., Vol. 21, No. 3, 2019

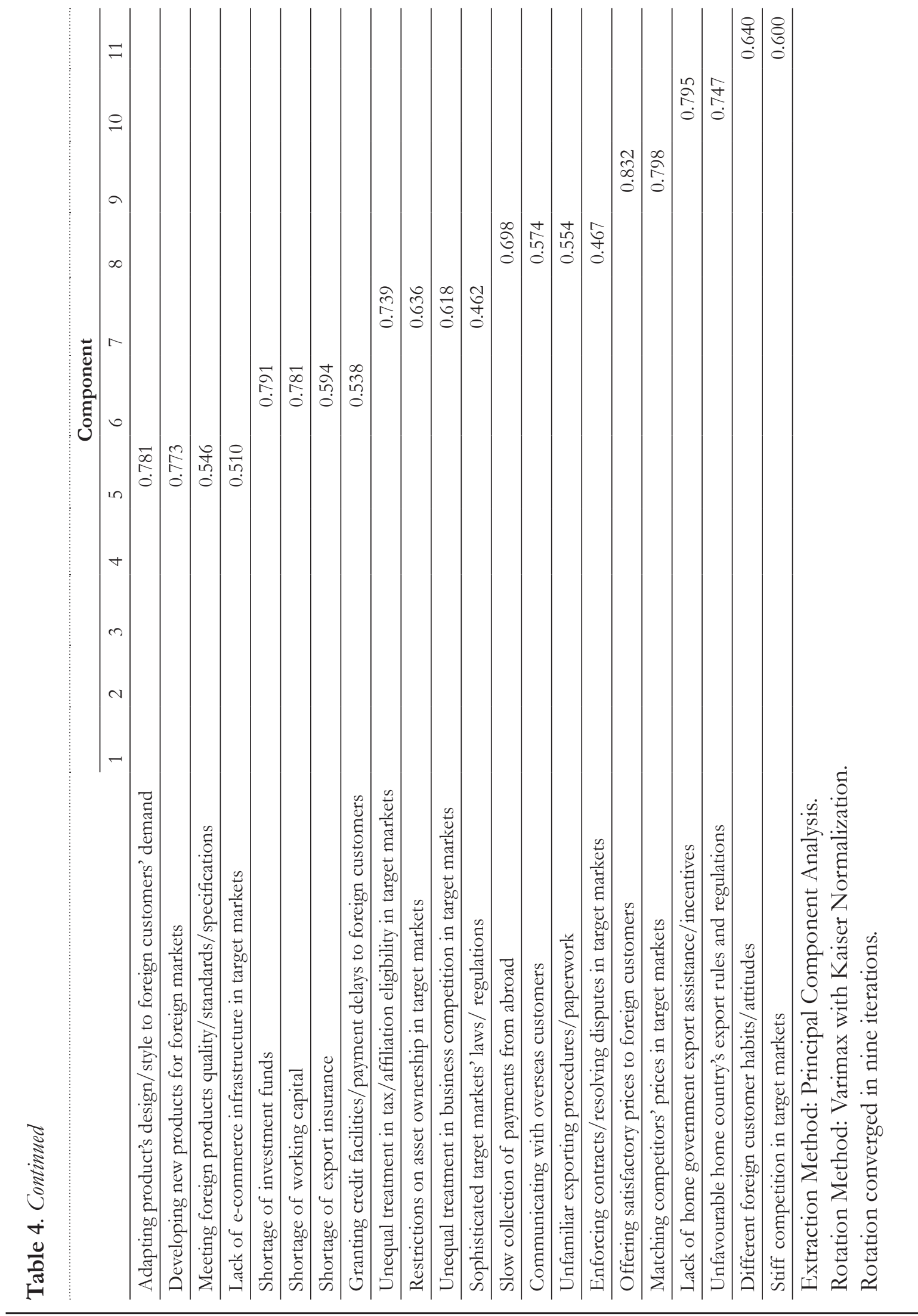


Table 5: Binary Logistic Estimates (Exporter-Non-Exporter Model)

\begin{tabular}{|c|c|c|c|c|c|}
\hline Independent Variables & $\begin{array}{r}\text { Estimated } \\
\text { Coefficients }\end{array}$ & $\begin{array}{r}\text { Standard } \\
\text { Error }\end{array}$ & $\begin{array}{r}\text { Wald } \\
\text { Statistics }\end{array}$ & Odds Ratio & $\begin{array}{r}\text { Marginal } \\
\text { Effects }\end{array}$ \\
\hline \multicolumn{6}{|l|}{ Enhancing Factors } \\
\hline OwnerStudy Abroad & -0.587 & 0.679 & 0.746 & 0.556 & -0.070 \\
\hline OwnerTrainAbroad & 0.848 & 0.876 & 0.937 & 2.336 & 0.101 \\
\hline OwnerWork Abroad & $1.632^{*}$ & 0.869 & 3.527 & 5.114 & 0.195 \\
\hline OwnerWorkMNC & 0.510 & 0.501 & 1.035 & 1.665 & 0.061 \\
\hline ProductXNational & $4.224 * *$ & 2.129 & 3.934 & 68.291 & 0.504 \\
\hline ProvinceXNational & $-0.319 * * *$ & 0.087 & 13.589 & 0.727 & -0.038 \\
\hline GovCentral_Assist & $1.148^{* * *}$ & 0.309 & 13.831 & 3.151 & 0.137 \\
\hline GovtLocal_Assist & -0.105 & 0.306 & 0.118 & 0.900 & -0.013 \\
\hline NonGovt_Assist & $2.504 * * *$ & 0.357 & 49.248 & 12.236 & 0.299 \\
\hline \multicolumn{6}{|l|}{ Inhibiting Factors } \\
\hline Barrier_Tariff & $-0.479 * * *$ & 0.142 & 11.474 & 0.619 & -0.057 \\
\hline Barrier_Human & $-0.624 * * *$ & 0.140 & 19.726 & 0.536 & -0.074 \\
\hline Barrier_Distribution & $-0.326^{* *}$ & 0.145 & 5.028 & 0.722 & -0.039 \\
\hline Barrier_ForeignEnviro & $-0.250 *$ & 0.148 & 2.877 & 0.779 & -0.030 \\
\hline Barrier_Product & 0.073 & 0.150 & 0.237 & 1.076 & 0.009 \\
\hline Barrier_Financial & -0.087 & 0.150 & 0.336 & 0.917 & -0.010 \\
\hline Barrier_ForeignGovt & -0.211 & 0.137 & 2.394 & 0.809 & -0.025 \\
\hline Barrier_Procedure & $-0.345^{* *}$ & 0.155 & 4.926 & 0.708 & -0.041 \\
\hline Barrier_Price & -0.227 & 0.139 & 2.679 & 0.797 & -0.027 \\
\hline Barrier_HomGovt & 0.134 & 0.142 & 0.888 & 1.143 & 0.016 \\
\hline Barrier_Customer & $-.307 * *$ & 0.140 & 4.826 & 0.735 & -0.037 \\
\hline \multicolumn{6}{|l|}{ SMEs' Characteristics } \\
\hline FirmAge & $0.036 * * *$ & 0.014 & 6.761 & 1.036 & 0.004 \\
\hline TotalEmployee & $0.017 * * *$ & 0.005 & 9.095 & 1.017 & 0.002 \\
\hline OwnerGender & 0.136 & 0.315 & 0.185 & 1.145 & 0.016 \\
\hline OwnerAge & 0.011 & 0.014 & 0.585 & 1.011 & 0.001 \\
\hline OwnerEducation & 0.016 & 0.122 & 0.016 & 1.016 & 0.002 \\
\hline Constant & $-2.558^{* * *}$ & 0.858 & 8.878 & & \\
\hline Total observations & & & 496 & & \\
\hline Degree of freedom & & & 25 & & \\
\hline-2 Log likelihood & & & 384.632 & & \\
\hline LR Chi-square & & & $298.698^{* * *}$ & & \\
\hline Pseudo R-squared (Cox \& Snell) & & & 0.452 & & \\
\hline \multicolumn{6}{|c|}{$\begin{array}{l}\text { Note: Dependent variable: Binary values, where } 1=\text { exporting SMEs and } 0=\text { non-exporting SMEs } \\
\left({ }^{*}\right),(* *) \text { and }(* * *) \text { represent } 10 \%, 5 \% \text {, and } 1 \% \text { significance levels, respectively. } \\
\text { Marginal effects are calculated as overall average marginal effects. }\end{array}$} \\
\hline Source: Author's calculation base & n the survey $\mathrm{d}$ & & & & \\
\hline
\end{tabular}


niques (Greene, 2008). To address this limitation, Table 5 also gives the calculated average marginal effects ${ }^{14}$ and odds ratio ${ }^{15}$. Marginal effects are more insightful to interpret the estimated coefficients of continuous explanatory variables, while the odds ratios are more meaningful to interpret the estimated coefficients of the dichotomous explanatory variables.

With respect to the SME owners' international exposure, only overseas work experience has a significant effect, while overseas study experience, overseas training experience and MNC/exporting firms' work experience have no significant effects on the SMEs' involvement in exporting activities. The owners' overseas work experience positively affects the SMEs' probability of exporting at the $10 \%$ significance level. SMEs whose owners have previously worked abroad are 5.114 times more likely, on average, to become exporters than SMEs whose owners are without such experience, other things being equal. SME owners with international work experience probably possess better tacit knowledge of foreign markets (e.g. the language, culture, business practices and regulations) and may have business contacts in foreign markets (Morosini et al., 1998; Ruzzier et al., 2007).

The estimated coefficient of ProductXNational is positive and significant at the $5 \%$ level. SMEs whose type of product/merchandise corresponds to Indonesia's main

${ }_{14}$ We use average marginal effect instead of marginal effect at the mean value of other explanatory variables because our model has several dichotomous (categorical) explanatory variables. For example, it is less intuitive to analyze the marginal effect of an explanatory variable on the dependent variable at the mean value of SME owners' gender because the gender variable takes binary values of either 1 (male) or 0 female).

${ }^{15}$ The odds ratio is obtained by the exponentiation of the estimated coefficients. In our model, it can be interpreted as the ratio of odds to become exporters given a one-unit change in the explanatory variable. export products are more likely to engage in export activities, and vice versa. On average, a one percentage point higher share of SMEs' types of products in Indonesia's total exports increases the probability of exporting by $0.5 \%$. This finding probably indicates the presence of "buyer effect" and of "copying/imitation effect" (Wengel and Rodriguez, 2006). SMEs have a better chance of exporting if they produce merchandise that already attracts foreign buyers (indicated by the merchandise's large share in national exports). SMEs also tend to copy or imitate the types of products sold in foreign markets.

In contrast, the coefficient of ProvinceXNational exhibits a negative sign (significant at the 1\% level). SMEs that operate in the provinces and have large shares in Indonesia's national exports exhibit a lower probability to export, or vice versa. This is possible if the exports in those provinces are dominated by large firms, traders or agents to which the SMEs prefer to sell their products rather than exporting directly themselves (Gereffi, 1994; Hessels and Terjesen, 2010). By selling to local exporters, SMEs can earn more than the domestic price for each unit of the product and avoid the risks of exporting, despite receiving less than the international price for their product.

The estimated coefficient of GovCentral_Assist is positive at the 1\% significance level. SMEs have a higher probability of exporting if they receive at least one of the following types of assistance from the central government agencies: promotional assistance (including trade expos, trade fairs, trade shows and SME catalogues), assistance in business management (e.g. managerial training), and assistance in finance and assistance in production (e.g. production techniques or equipment). More specifically, 
SMEs that are recipients of central government agencies' assistance, on average, are 3.151 times more likely to become exporters than non-recipient SMEs, all else being equal.

However, the assistance provided by local government agencies does not have a similar effect on export engagement. The estimated coefficient of GovtLocal_Assist is negative and insignificant. Technical training, managerial training, grants of equipment, grants of capital and trade fairs organized by provincial, municipal or regency governments do not significantly increase the SMEs' probability of engaging in exporting activities. The contradictory effect of central and local government agencies' assistance in SME internationalization is possible since the central government agencies may have a better vision of global market opportunities for SMEs, whereas the local government agencies may have a stronger local or domestic market orientation in their assistance (Uchikawa and Keola, 2008).

The estimated coefficient of NonGovt_ Assist is positive and significant at the 1\% level, which implies that the assistance provided by non-governmental network sources has a positive influence on the SMEs' probability of becoming exporters. SMEs are more likely to be involved in export activities if they receive financial, technical, managerial and promotional assistance from various non-governmental informal sources (family, relatives, business associates and emigrant communities) or formal non-governmental sources (including business chambers/associations, SOEs and universities/ research institutes). More precisely, SMEs who are recipients of assistance provided by non-governmental network sources are 12.236 times more likely, on average, to engage in exporting than non-recipient SMEs, all other things being equal. This finding reaffirms the importance of network relationships in SMEs' internationalization, as reported by previous studies (Battaglia et al., 2006; Coviello and Munro, 1997; Freeman et al., 2006; Ojala, 2009; Senik et al., 2011).

Of the 11 variables that represent export-inhibiting factors, six variables have significant effects on SMEs' probability to export, including Barrier_Tariff, Barrier_Human, Barrier_Distribution, Barrier_Procedure, Barrier_ForeignEnviro and Barrier_Customer. However, the estimated coefficients, marginal effects, and odds ratio of those variables are not too insightful for interpretation, because they are composite variables obtained from the PCA's factor extraction and each barrier is measured by the perceived difficulties using the Likert-scale method. Hence, we focus the analysis on the estimated signs of the coefficients that indicate the direction of the effect of perceived export barriers on SMEs' export involvement. As expected, the estimated coefficients of those six variables are negative, which imply that the more difficult the SMEs perceive those barriers to be, the lower the probability is that they will become exporters. In other words, SMEs are less likely to export if they perceive great difficulties with tariff and non-tariff barriers, informational and human resource barriers, distribution, logistic, and promotional barriers, business environment barriers in the host countries, procedural barriers, and foreign customer and competitor barriers.

However, the estimated coefficients of Barrier_Product, Barrier_Financial, Barrier_ForeignGovt, Barrier_Price and Barrier_HomGovt are not statistically significant. Hence, the perceived difficulties of product and transaction barriers, financial barriers, foreign government barriers, price barriers, and 
home government barriers do not affect the SMEs' probability to export. These findings assert that export barriers are crucial in the SMEs' internationalization but the levels of difficulty/severity vary across the types of barriers (OECD, 2008, 2009).

Two variables that represent firm characteristics have the expected signs and significant estimated coefficients. The estimated coefficients of Firm Age and TotalEmployee are both positive and significant at the 1\% level. More experienced SMEs have a higher probability of engaging in exporting activities. In particular, one additional year of firm age increases the probability to export by 0.004 , on average, all else being equal. Established SMEs are more likely to have capital available, or already secured, an established administrative structure and decision-making process, and plans on how to expand or grow (Brush, 2012). Firm size also positively influences the probability of exporting. One additional employee increases the SMEs' probability to export by 0.002 , on average, all else being equal. SMEs with larger numbers of employees may have a better ability to upgrade their product's quality and to meet foreign buyers' requirements (Ottaviano and Martincus, 2011). The SME owners' characteristics, however, have no significant effect on the SMEs' probability of exporting. The estimated coefficients of OwnerAge, OwnersEducation and OwnerGender have the expected positive signs, but none is statistically significant.

\section{Binary Logit Estimation for Export- er-Aspiring-Exporter Model}

We exclude non-intender SMEs (non-exporting SMEs with no intention to export) from the export engagement analysis and focus on the aspiring-exporters (non-exporting
SMEs with the intention and plans to export in the future). The Omnibus Tests of Model Coefficients yield a Chi-square statistic of 155.797 with 25 degrees of freedom and are significantly different from zero at the $1 \%$ level. Furthermore, the model's -2 Log likelihood value of 311.999 implies that the model with the explanatory variables is a significantly better fit than the null model. These results indicate that the explanatory variables employed in the models significantly improve the baseline model, which only includes the constant. In other words, the 25 explanatory variables used in the model significantly improve the model's ability to explain the variation of the outcome (the exporting or aspiring-exporter status of the SMEs). In particular, the Cox and Snell Pseudo R-square of 0.333 and the Nagelkerke Pseudo R-square of 0.473 indicate that the model can explain a considerable share of the variation in the outcome. The Hosmer and Lemeshow test yields a Chi-square value of 14.244 and $\mathrm{p}=$ $0.076(>0.05)$, which suggests the model is a good fit of the data. More precisely, the model (with its 25 explanatory variables) has $82.1 \%$ success in classifying/predicting the SME's probability of engaging in exporting.

Overall, those specification test results indicate that both the exporter-non-exporter and exporter-aspiring-exporter models have good explanatory powers and fit the survey data. However, the exporter-aspiring-exporter model has a lower Chi-square statistics value of the omnibus test, a lower - 2 Log likelihood value, lower pseudo-R square values, and a slightly lower percentage success in predicting the outcome than the exporter-non-exporter model. These results suggest that the exporter-aspiring-exporter model has slightly less explanatory power than the exporter-non-exporter model. In addition, the Hosmer and Lemeshow test value 
Revindo et al.

Table 6: Binary Logistic Estimates (Exporter-Aspiring-Exporter Model)

\begin{tabular}{|c|c|c|c|c|c|}
\hline Independent Variables & $\begin{array}{r}\text { Estimated } \\
\text { Coefficients }\end{array}$ & $\begin{array}{r}\text { Standard } \\
\text { Error }\end{array}$ & $\begin{array}{r}\text { Wald } \\
\text { Statistics }\end{array}$ & Odds Ratio & $\begin{array}{l}\text { Marginal } \\
\text { Effects }\end{array}$ \\
\hline \multicolumn{6}{|l|}{ Enbancing Factors } \\
\hline OwnerStudy Abroad & -0.657 & 0.693 & 0.898 & 0.518 & -0.086 \\
\hline OwnerTrainAbroad & 0.654 & 0.934 & 0.491 & 1.924 & 0.086 \\
\hline OwnerWork.Abroad & $1.644^{*}$ & 0.935 & 3.095 & 5.178 & 0.216 \\
\hline OwnerWork:MNC & $1.016^{*}$ & 0.589 & 2.980 & 2.762 & 0.133 \\
\hline ProductXNational & $6.132^{* *}$ & 2.474 & 6.141 & 460.198 & 0.804 \\
\hline ProvinceXNational & $-0.297 * * *$ & 0.092 & 10.305 & 0.743 & -0.039 \\
\hline GovCentral_Assist & $0.701 * *$ & 0.331 & 4.486 & 2.017 & 0.092 \\
\hline GovtLocal_Assist & -0.132 & 0.335 & 0.156 & 0.876 & -0.017 \\
\hline NonGovt_Assist & $0.900^{* *}$ & 0.420 & 4.588 & 2.460 & 0.118 \\
\hline \multicolumn{6}{|l|}{ Inhibiting Factors } \\
\hline Barrier_Tariff & $-0.531^{* * *}$ & 0.163 & 10.617 & 0.588 & -0.070 \\
\hline Barrier_Human & $-0.822^{* * *}$ & 0.163 & 25.370 & 0.440 & -0.108 \\
\hline Barrier_Distribution & $-0.286^{*}$ & 0.154 & 3.471 & 0.751 & -0.038 \\
\hline Barrier_ForeignEnviro & $-0.319 *$ & 0.164 & 3.757 & 0.727 & -0.042 \\
\hline Barrier_Product & 0.118 & 0.170 & 0.477 & 1.125 & 0.015 \\
\hline Barrier_Financial & -0.119 & 0.170 & 0.491 & 0.887 & -0.016 \\
\hline Barrier_ForeignGovt & -0.236 & 0.152 & 2.405 & 0.790 & -0.031 \\
\hline Barrier_Procedur & $-0.412^{* *}$ & 0.172 & 5.762 & 0.662 & -0.054 \\
\hline Barrier_Price & -0.208 & 0.149 & 1.942 & 0.813 & -0.027 \\
\hline Barrier_HomGovt & 0.197 & 0.156 & 1.594 & 1.218 & 0.026 \\
\hline Barrier_Customer & -0.220 & 0.153 & 2.080 & 0.802 & -0.029 \\
\hline \multicolumn{6}{|l|}{ SMEs' Characteristics } \\
\hline FirmAge & $0.061 * * *$ & 0.019 & 10.481 & 1.063 & 0.008 \\
\hline TotalEmployee & $0.018^{* * *}$ & 0.006 & 7.651 & 1.018 & 0.002 \\
\hline OwnerGender & 0.001 & 0.344 & 0.000 & 1.001 & 0.000 \\
\hline OwnerAge & 0.017 & 0.015 & 1.141 & 1.017 & 0.002 \\
\hline OwnerEducation & 0.031 & 0.139 & 0.050 & 1.032 & 0.004 \\
\hline Constant & $-1.591 *$ & 0.939 & 2.872 & & \\
\hline Total observations & & & 385 & & \\
\hline Degree of freedom & & & 25 & & \\
\hline -2 Log likelihood & & & 311.999 & & \\
\hline LR Chi-square & & & $155.797 * * *$ & & \\
\hline $\begin{array}{l}\text { Pseudo R-squared (Cox \& } \\
\text { Snell) }\end{array}$ & & & 0.333 & & \\
\hline
\end{tabular}

Note: $\quad$ Dependent variable: Binary values, where $1=$ exporting SMEs and $0=$ aspiring-exporters $(*),\left({ }^{* *}\right)$ and $(* * *)$ represent $10 \%, 5 \%$, and $1 \%$ significance levels, respectively.

Marginal effects are calculated as overall average marginal effects.

Source: Author's calculation based on the survey data. 
shows that the exporter-aspiring-exporter model does not fit the data as well as the exporter-non-exporter model. This is possible since exporting SMEs have greater contrasting characteristics with non-exporting SMEs than with aspiring-exporters. In addition, the exporter-aspiring-exporter model $(\mathrm{N}=385)$ has a smaller sample size than the exporter-non-exporter model $(\mathrm{N}=497)$.

The exporter-aspiring-exporter model uses the same set of 25 explanatory variables as the exporter-non-exporter model. The estimations of the two models give exactly the same signs of the estimated coefficients of all the explanatory variables, despite different marginal effects and odds ratios. However, the two models differ in the set of explanatory variables that are statistically significant. In the exporter-aspiring-exporter estimation results, the estimated coefficient of OwnerWorkMNC is now significant (insignificant in the exporter-non-exporter model) and the estimated coefficient of Barrier_Customer is now insignificant (significant in the exporter-non-exporter model). We therefore focus our analysis on the estimated coefficients of these two variables.

In terms of the SME owners' international exposure, in addition to OwnerWorkAbroad, OwnerWorkMNC is positive and significant at the $10 \%$ level. Hence, in addition to the positive effect of the SME owners' overseas work experience, MNC experience or experience from working at an exporting firm also increases the SMEs' probability of engaging in export activities. In particular, the owners of SMEs who have previously worked for MNC or other exporting firms are 2.762 times more likely, on average, to become exporters than the owners of SMEs who have no such experience, other things being equal. This is possible since an
SME owner with MNC experience or experience of working for an exporting firm is likely to have better international business skills, information about and contacts in foreign markets, and knowledge of international trade policies and exchange rate risks (Carpenter et al., 2000; Ruzzier et al., 2007).

With respect to the inhibiting factors, the estimated coefficient of Barrier_Customer is now insignificant despite being previously significant in the exporter-non-exporter model. For non-exporting SMEs in general, foreign customers and competitor barriers are significant impediments to exporting, but for aspiring-exporters these types of barriers do not seriously hamper their attempts to engage in export activities.

\section{Conclusion}

This study investigates the factors influencing SMEs' engagement in direct export activities. The binary logistic regressions were used to investigate the factors distinguishing exporting SMEs and non-exporting SMEs. Three groups of explanatory variables were employed, including export enhancing factors, export inhibiting factors and SMEs' characteristics.

In terms of the SMEs' characteristics, the results showed that firms' operational experience (firm age), and firm size (number of employees) positively correlate with the probability of being involved in export markets. In terms of export enhancing factors, the results showed that SMEs have a higher probability of exporting if the owners have been overseas or have experience working for MNC or an exporting firm. The SMEs' propensity to export is enhanced if they produce merchandise that comprises a large share of Indonesia's national exports (buyer 
effect and copying/imitation effect) and operate in the provinces that make a small contribution to Indonesia's total exports (fewer large exporting companies in the province).

SMEs also have a higher probability of exporting if they receive assistance from central government agencies (including promotional, business management, finance, and production assistance) or receive financial, technical, managerial, and promotional assistance from various non-governmental sources including informal sources (family, relatives, business associates, and emigrant communities) and formal non-governmental sources (business chambers/associations, SOEs, and universities/research institutes).

On the contrary, the SMEs' propensity to export is inhibited if they perceive difficulties in overcoming any tariff and non-tariff barriers, informational and human resource barriers, distribution, logistic, and promotional barriers, business environment barriers in host countries, procedural barriers, and foreign customer and competitor barriers.

The findings of the study have academic significance. First, we have shown that the general model of export engagement determinants is more applicable for SMEs, as compared to the model of expected monetary cost and the benefits gained from exporting. Second, we introduced a comprehensive set of independent variables, from which future research can be developed. Third, the division of SMEs at the pre-export stage into aspiring exporters and non-intenders matters when analyzing the probability of the SMEs' involvement in exports. Accordingly, future research into the SMEs' internationalization can focus more on SMEs with a strong intention to export.

The findings of the study also have several policy implications. First, the gov- ernment can identify SMEs with export potential and subsequently prioritize their participation in export assistance programs. Potential exporters can be identified from their firms' characteristics, owners' characteristics, network relationships and their perceptions of export barriers. Second, the government should design export assistance based on accurate information about the severity of the export impediments faced by SMEs. Accordingly, the government should have a good understanding of the types and the severity of the export barriers faced by SMEs, so that effective and focused policy measures to remove the export barriers can be formulated. Third, the government should be knowledgeable about the functions and role of non-government actors in the internationalization network, such as business associations/chambers, research institutes/ universities, finance/ microfinance institutions, and other non-government organizations. The government should look to strengthen the operation of those networking sources, or assign a public body to facilitate, connect, coordinate, and monitor the myriads of private and public agencies that have the same areas of interest or assistance.

The findings of the study also have managerial implications. First, the aspiring-exporters should proactively seek export assistance from central government agencies. Second, aspiring-exporters should also develop and maintain close relationships with non-government actors in the networks. Some network actors that can help the SMEs to internationalize include, but are not limited to, business associations/chambers, business partners/associates, private companies/ state-owned enterprises, universities/research institutes, suppliers, distributors, and Indonesian emigrant communities worldwide. Network relationships with non-government ac- 
tors in the network can be as important as the formal relationships with government agencies in facilitating the SMEs to export.

The study has some limitations, upon which future research into this topic can be developed. First, the 50 types of export inhibiting factors were measured with perceptual data. Future studies can replace that with factual (quantitative) data. For example, the actual tariff rate, number of export documents, cost of exporting and time taken to export can be used to replace the perceptual barriers related to procedure and logistics barriers.

Second, we used the SMEs' points of view in elaborating the role of provincial and municipal governments in the provision of export assistance programs. Future studies can elicit perspectives from local government agencies, as their roles in policymaking in Indonesia have been increasingly important since the implementation of regional autonomy in 2001 (Badrudin and Siregar, 2015).
Third, we used the SMEs' points of view in elaborating the role of the private actors in the internationalization networks. Future studies can elicit perpsectives from distributors, suppliers, business associations/chambers, financial institutions and other private agencies to have a better understanding on how the network relationships can help foster SMEs to internationalize.

Finally, future research can focus on SME internationalization in a particular province/ region or product group/industry. For example, case studies of SMEs' internationalization in tourist destination provinces such as Bali and Yogyakarta can be considered. Case studies can also be drawn from the internationalization of SMEs in specific industries such as handicrafts, food and beverages, and garment and fashion accessories. Specific case studies will allow more specific policy measures to be recommended to foster the SMEs participation in export markets.

\section{References}

Anderson, D. R., Sweeney, D. J., and Williams, T. A. (2010). Statistics for Business and Economics (11th ed.): South Western Educational Publishing.

Awuah, G. B., and Amal, M. (2011). Impact of globalization: the ability of less developed countries' (LDCs') firms to cope with opportunities and challenges. European Business Review, 23(1), 120-132. doi:10.1108/09555341111098026

Badrudin, R., and Siregar, B. (2015). The evaluation of the implementation of regional autonomy in Indonesia. Economic Journal of Emerging Markets, 7(1), 1-11.

Battaglia, L., Corsaro, D., and Tzannis, A. (2006). The role of networks in the internationalisation of a SME: the case of an Italian company. Paper presented at the Industrial Marketing and Purchasing Group Conference, Milano. http://impgroup.org/uploads/papers/5624.pdf

Bernard, A. B., and Jensen, J. B. (2004). Why some firms export. Review of Economics and Statistics, 86(2), 561-569.

BPS-Statistics Indonesia. (2014a). Industri Statistics. Retrieved from http://www.bps.go.id/

BPS-Statistics Indonesia. (2014b). Statistical Yearbook of Indonesia 2014. Retrieved from Jakarta: https://www.bps.go.id/website/pdf_publikasi/ 
Brush, C. (2012). International Entrepreneurship: The Effect of Firm Age on Motives for Internationalization (Vol. 5): Routledge.

Carpenter, M. A., Sanders, W. G., and Gregersen, H. B. (2000). International assignment experience at the top can make a bottom-line difference. Human Resource Management, 39(2, 3), 277.

Coviello, N., and Munro, H. (1997). Network relationships and the internationalisation process of small software firms. International Business Review, 6(4), 361-386. doi:10.1016/s09695931(97)00010-3

Crossley, M. L. (2008). The Desk Reference of Statistical Quality Methods (S. Edition Ed.): ASQ Quality Press.

Dabić, M., Maley, J., Dana, L.-P., Novak, I., Pellegrini, M. M., and Caputo, A. (2019). Pathways of SME internationalization: a bibliometric and systematic review. Small Business Economics, 1-21.

DiStefano, C., Zhu, M., and Mindrila, D. (2009). Understanding and using factor scores: Considerations for the applied researcher. Practical Assessment, Research and Evaluation, 14(20), $1-11$.

Fakih, A., and L. Ghazalian, P. (2014). Which firms export? An empirical analysis for the manufacturing sector in the MENA region. Journal of Economic Studies, 41(5), 672-695.

Firmanzah, F. (2008). Enhancing Foreign Consumer Acceptance The Role of Capabilities of Creating Export-Market Oriented Products in Small and Medium-Sized Enterprises (SMEs). Gadjah Mada International Journal of Business, 10(2), 237-259.

Freeman, S., Edwards, R., and Schroder, B. (2006). How smaller born-global firms use networks and alliances to overcome constraints to rapid internationalization. Journal of International Marketing, 14(3), 33-63. doi:10.2307/25049054

García-Cabrera, A. M., García-Soto, M. G., and Suárez-Ortega, S. M. (2017). Macro-level spillovers and micro-level capabilities as antecedents of young SMEs' propensity to export and to become a born global. International entrepreneurship management journal, 13(4), 11991220.

Gereffi, G. (1994). The Organization of Buyer-Driven Global Commodity Chains: How US Retailers Shape Overseas Production Networks. In G. Gereffi and M. Korzeniewicz (Eds.), Commodity chains and global capitalism. London: Praeger.

Greene, W. H. (2008). Econometric analysis (6th ed.): Pearson.

Haddoud, M. Y., Beynon, M. J., Jones, P., and Newbery, R. (2018). SMEs' export propensity in North Africa: a fuzzy c-means cluster analysis. Journal of Small Business Enterprise Development, 25(5), 769-790.

Hammer, A., and Stamps, J. (2010). The Role of Small and Medium Sized Enterprises In U.S. and EU Exports. Retrieved from Paris: http://www.oecd.org/officialdocuments/publicdisplaydocumentpdf $/$ cote $=$ STD $/$ TBS/WPTGS(2010)18\&docLanguage $=$ En .

Hessels, J., and Terjesen, S. (2010). Resource dependency and institutional theory perspectives on direct and indirect export choices. Small Business Economics, 34(2), 203-220. doi:10.1007/ s11187-008-9156-4

Hill, R. C., Griffiths, W. E., and Lim, G. C. (2011). Principles of econometrics (Fourth ed.): John Wiley and Sons, Inc. 
Gadjah Mada International Journal of Business - Sept.-Dec., Vol. 21, No. 3, 2019

Indrawan, R. (2019). Sinergitas Pengembangan KUMKM melalui Penguatan Peran Antar Lembaga. Bali: Sekretaris Kementerian Koperasi dan UKM

ITC. (2019). Trade Map: Export by Products. Retrieved 1 May 2018, from The International Trade Centre http://www.trademap.org/Index.aspx.

Knight, G. (2000). Entrepreneurship and marketing strategy: The SME under globalization. Journal of International Marketing, 8(2), 12-32.

Laghzaoui, S. (2007). Internationalization of SME: A reading in terms of resources and competencies. Paper presented at the 3rd Iberian International Business Conference, Aveiro, Portugal.

Lee, C. F., Lee, J. C., and Lee, A. C. (1999). Statistics for business and financial economics (Second ed.). Singapore: World Scientific.

Leonidou, L. C. (2004). An analysis of the barriers hindering small business export development. Journal of Small Business Management, 42(3), 279-302. doi:10.1111/j.1540627X.2004.00112.x

Maddala, G. S. (2001). Introduction to econometrics (Third ed.): John Wiley and Sons Ltd.

McFadden, D. (1977). Quantitative methods for analyzing travel behavior of individuals: some recent developments. In D. A. Hensher and D. A. Stopher (Eds.), Behavioral Travel Modelling (pp. 279-318). London: Groom Helm.

Ministry of Cooperatives and SMEs Republic of Indonesia. (2009). Direktori KUKM Ekspor. In. Jakarta.

Ministry of Cooperatives and SMEs Republic of Indonesia. (2011). SME and Cooperative Indonesia Catalogue. In. Jakarta.

Ministry of Cooperatives and SMEs Republic of Indonesia. (2012). SME and Cooperative Indonesia Catalogue. In. Jakarta.

Ministry of Cooperatives and SMEs Republic of Indonesia. (2015). Micro, Small and Medium-sized Enterprises Data. Retrieved from http://www.depkop.go.id/berita-informasi/ data-informasi/data-umkm/

Morosini, P., Shane, S., and Singh, H. (1998). National cultural distance and cross-border acquisition performance. Journal of International Business Studies, 29(1), 137-158.

OECD-APEC. (2006). Removing Barriers to SME Access to International Markets. Paper presented at the OECD-APEC Global Conference, Athens.

OECD. (2008). Removing Barriers to SME Access to International Markets: Secretary-General of the OECD,.

OECD. (2009). Top Barriers and Drivers to SME Internationalisation (OECD Ed.): The OECD Working Party on SMEs and Entrepreneurship.

OECD. (2012). Fostering SMEs' Participation in Global Markets: OECD.

Ojala, A. (2009). Internationalization of knowledge-intensive SMEs: The role of network relationships in the entry to a psychically distant market. International Business Review, 18(1), 50-59. doi:10.1016/j.ibusrev.2008.10.002

Ottaviano, G., and Martincus, C. V. (2011). SMEs in Argentina: who are the exporters? Small Business Economics, 37(3), 341-361.

Pendergast, W. R., Sunje, A., and Pasic, M. (2008). The internationalization of SMEs in Bosnia and Herzegovina. In L.-P. Dana, I. M. Wellpe, M. Han, and V. Ratten (Eds.), Handbook of Research on European Entrepreneurship: Towards a Theory of Internationalization (pp. 94-113). 
London: Edward Elgar.

Putra, P. O. H., and Hasibuan, Z. A. (2015). The relationship between enterprise internationalization and E-business adoption: A perspective of Indonesian SMEs. Paper presented at the 2015 International Conference on Information Society (i-Society).

Republic of Indonesia. (2008). Law on Micro, Small and Medium-sized Enterprise Number 20. Jakarta

Revindo, M. D. (2018). Types and Severities of Export Barriers: Evidence from Indonesian SMEs. Economics and Finance in Indonesia, 63(2), 150-175.

Revindo, M. D., and Gan, C. (2016). Export Stimuli, Export Stages and Internationalization Pathways: The Case of Indonesian SMEs. EFI, 62(3), 191-205.

Ribau, C. P., Moreira, A. C., and Raposo, M. (2018). SME internationalization research: Mapping the state of the art. 35(2), 280-303.

Roberts, M. J., and Tybout, J. R. (1997). The decision to export in Colombia: An empirical model of entry with sunk costs. The American Economic Review, 87(4), 545-564. doi: $10.2307 / 2951363$

Roida, H. Y., and Sunarjanto, N. A. (2012). Family ownership type and the international involvement of SMEs: Empirical study of agency theory in East Java Indonesia. Chinese Business Review, 11(2), 224-232.

Ruzzier, M., Antoncic, B., Hisrich, R. D., and Konecnik, M. (2007). Human capital and SME internationalization: A structural equation modeling study. Canadian Journal of Administrative Sciences/Revue Canadienne des Sciences de l'Administration, 24(1), 15-29.

Ruzzier, M., Hisrich, R. D., and Antoncic, B. (2006). SME internationalization research: past, present, and future. Journal of Small Business and Enterprise Development, 13(4), 476-497.

Sabila, F. (2014). Perancangan Promosi Produk UKM Plasa Pameran Kementerian Perindustrian. Universitas Multimedia Nusantara,

Sari, D. (2011). Internationalisation of Manufacturing SMEs: The Case of Indonesia. Paper presented at the International Council for Small Business (ICSB) World Conference Washington.

Sari, D., Alam, Q., and Beaumont, N. (2008). Internationalisation of SMEs in Indonesia: Entrepreneur buman and social capital Working Papers in Business, Management and Finance No. 200801. Padjadjaran University. Bandung.

Senik, Z. C., Scott-Ladd, B., Entrekin, L., and Adham, K. A. (2011). Networking and internationalization of SMEs in emerging economies. Journal of International Entrepreneurship, 9(4), 259-281. doi:10.1007/s10843-011-0078-x

Senik, Z. C., and Sham, R. M. (2011). SME internationalization intelligence information and knowledge on international opportunities. Gadjah Mada International Journal of Business, 13(2), 161-183.

Shih, T.-Y., and Wickramasekera, R. (2011). Export decisions within Taiwanese electrical and electronic SMEs: The role of management characteristics and attitudes. Asia Pacific Journal of Management, 28(2), 353-377. doi:10.1007/s10490-010-9213-9

Shu, P., and Steinwender, C. (2019). The impact of trade liberalization on firm productivity and innovation. Innovation Policy and the Economy, 19(1), 39-68.

Tambunan, T. (2009a). Export-oriented small and medium industry clusters in Indonesia. Journal of Enterprising Communities: People and Places in the Global Economy, 3(1), 25-25. 
doi:10.1108/17506200910943661

Tambunan, T. (2009b). Facilitating small and medium enterprises in international trade (export): The case of Indonesia. Paper presented at the Asia-Pacific Trade Economists' Conference: Trade-Led Growth in Times of Crisis, Bangkok, Thailand.

Tambunan, T. (2012). Main Constraints Facing Export-Oriented Micro, Small and Medium Enterprises in Indonesia: Secondary Data Analysis and Literature Survey. Retrieved from

Uchikawa, S., and Keola, S. (2008). Small and medium enterprises in Cambodia, Laos, and Vietnam. ERIA Research Project Report 2008(5), 237-273.

Wengel, J. t., and Rodriguez, E. (2006). SME export performance in Indonesia after the crisis. Small Business Economics, 26(1), 25-37. doi:10.1007/s11187-004-6491-y

Wignaraja, G. (2012). Engaging Small and Medium Enterprises in Production Networks: Firm-level Analysis of Five ASEAN Economies. In ADBI Working Paper Series No. 361: ADBI.

Yang, Y. S., Leone, R. P., and Alden, D. L. (1992). A market expansion ability approach to identify potential exporters. The Journal of Marketing, 56(1), 84-96.

Yi, J., and Wang, C. (2012). The decision to export: Firm heterogeneity, sunk costs, and spatial concentration. International Business Review, 21(5), 766-781. doi:http://dx.doi.org/10.1016/j. ibusrev.2011.09.001

Yoshino, N., and Wignaraja, G. (2015). SMEs Internationalization and Finance in Asia. Paper presented at the Frontier and Developing Asia: Supporting Rapid and Inclusive Growth IMF-JICA Conference Tokyo. 